\title{
Assessment of Sustainable Livelihood Assets of Farming Households in Akwa Ibom State, Nigeria
}

\author{
Edet J. Udoh ${ }^{1}$, Sunday B. Akpan ${ }^{2} \&$ Edikan Francis Uko ${ }^{1}$ \\ ${ }^{1}$ Department of Agricultural Economics and Extension, University of Uyo, Akwa Ibom State, Nigeria \\ ${ }^{2}$ Department of Agricultural Economics and Extension, Akwa Ibom State University, Nigeria \\ Correspondence: Edet J. Udoh, Department of Agricultural Economics and Extension, University of Uyo, Akwa \\ Ibom State, Nigeria. E-mail: ej_udoh@hotmail.com
}

Received: May 4, $2017 \quad$ Accepted: May 24, $2017 \quad$ Online Published: July 30, 2017

doi:10.5539/jsd.v10n4p83

URL: https://doi.org/10.5539/jsd.v10n4p83

\begin{abstract}
There is surfeit of evidence on increase poverty and low agricultural productivity among majority of rural dwellers in Nigeria. Researches have established an inverse linked between rural poverty and sustainable households' asset based. Agricultural production, being the major livelihood source for majority of rural dwellers needs considerable asset or capital for it to be considered as sustainable. Based on this assertion, the study assesses the sustainable livelihood assets of farming households in Abak Local Government area of Akwa Ibom state in Southern region of Nigeria. A multi-stage sampling technique was employed to select 110 farming household heads in the study area. Structured questionnaires were used to collect cross sectional data from respondents. Descriptive tools were used to analyse data collected. The socioeconomic features of respondents revealed a sample population that is fast ageing, dominated by married male and moderately educated. Result also showed that, respondents had considerable piles of physical, social and natural assets to assist in livelihood sustenance. However, the index of capacity structure of sustainable livelihood assets revealed a huge deficiency in financial and human assets among farming households in the region. Hence, it is recommended that, farming households should increase their human assets by encouraging education of the younger household members. Also, efforts should be made to improve social capital formation among farming households and communities.
\end{abstract}

Keywords: Akwa Ibom State, farming household, livelihood asset, poverty, sustainability

\section{Introduction}

Livelihood sustainability is an evolving issue especially in the developing economies given the increasing level of poverty, hunger, starvation, economic backwardness and poor agricultural system prevalent in the region (Ashley, 2000; Bauman, 2000; Turton, 2000 and Nicol, 2000). Following the scholarly work of Krantz (2001), a livelihood comprises of the capabilities, assets (stores, resources, claims and access) and activities required for a means of living. He also asserted that, livelihood is sustainable when it can cope with and recover from stresses and shocks, maintain or enhance its capabilities and assets, and provide sustainable livelihood opportunities for the next generation; and which contributes net benefits to other livelihoods at the local and global levels and in the short and long term. Hence, a livelihood constitutes of adequate stocks and flows of food and cash to meet basic needs of life and it comprises people, their capabilities and means of living including income and assets. The assets could be tangible or intangible assets. Tangible assets are physical resources while intangible assets are claims and access. Also, a livelihood is environmentally sustainable when it contributes to the stability of environmental assets and has a sustainable positive net benefit effects on other livelihoods sources (Stephen, Nora and Moses 2009).

In determining the level of sustainability of household livelihood, five principal assets or capital are often considered. These assets contribute or enhance the situation of a family by responding to shocks and stresses as they adjust to overcome them and stayed sustainable over a period of time. The five pillars (capital) of sustainable livelihood as proposed by Scoones (1998) include: natural, human, financial, physical and social capitals. The natural capital consists of resource stocks such as: soil, water, air, genetic resources etc. that is used to support livelihood activities of household. Also environmental services such as shade, pollution sinks, and hydrological cycles among others are included in this category. By definitions, human capital represents the skills, knowledge, experience and ability of human labour or other intangible assets of individuals that can be 
used to create economic value for the individuals, families, employers, communities, society and the nation. At a household level, human capital represents the amount and quality of household labour available; this varies according to household size, skill level, leadership potential, health status among others. Human capital appears in the generic framework as a building block or means of achieving livelihood outcomes. In a similar vein, social capital in the context of sustainable livelihood means the social resources upon which people built or form in pursuit of their livelihood objectives. These are developed through networks and connectedness, membership of more formalized groups and relationship of trust, reciprocity and exchange. In addition, within the context of household livelihood, physical capital comprises the basic infrastructures and producer goods needed to support livelihoods. They are items of economic, commercial or exchange value that has a tangible or material existence. For instance, household's cash, farm tools and equipment, family inventory and other properties owned by member of the family.

Another importance form of sustainable capital is the financial capital. This refers to the financial resources such as cash, liquid assets, pension, remittances and the like (Scoones, 1998). Financial capital denotes resources that people use to achieve their livelihood objectives. Some of these capitals are straight forward i.e. buildings, machinery, land, cash etc., while some are less immediately obvious such as social networks, knowledge and good health (Morse et al., 2009). All are important although clearly the balance in the used of these capitals changes from one household to another over time. Once the balance has been identified using capital pentagon, it will be easier to assess the contribution of each capital and explore the vulnerability context (trend, shocks and stresses) in which they exist at the household. Each of the capital asset discussed previously has index or indicator that reveals its accessibility, availability and other vital information that could be used to access individual household. It is also worth to note, that a single household asset such as land can generate multiple or stream of benefits. For example if a household has secure access to land, they are likely to be well endowed with financial assets as they can use the land for productive purposes and to secure loans (Chambers, 1995 \& DFID, 2000). Literature has also provided evidence that household capitals showed varied degrees of resilience with respect to shock or stress intensity (Odero 2006). For instance, some assets changes little over time while others such as cash and social network can be volatile and depend upon movement of people into and out of the household. Also, drought will impact upon natural capital and in turn reduce yield, but may have little effect on other capitals. In the longer term, of course a severe drought could impact on a wide range of capital including social and human capital while having little impact on others.

It has been observed that in spite of abundant natural, physical and human resources that Nigeria is endowed with, there is still high incidence of poverty and poor livelihood potentials especially in the rural areas (Ngbea and Achunike, 2014, Nwagwu, 2014). The deteriorating physical assets in the rural areas have aggravated the incidence of poverty and stamped growth in human asset as well as the social assets. The major source of livelihood activity of the rural dwellers in Nigeria is agriculture; and evidence abound that small scale agriculture practiced by majority of these rural dwellers lacks sufficient incentives needed for optimal household livelihood sustainability. The country's agricultural sector is faced with several challenges such as; poor land ownership structure, low level of irrigation development, limited adoption of research findings, high cost of farm inputs, poor access to credit, inefficient fertilizer procurement and distribution, inadequate storage facilities and poor access to markets have all combined to keep agricultural productivity low with high postharvest losses and waste (Akpan et al., 2012). In the southern region of Nigeria, specifically, Akwa Ibom state, the picture of agricultural sector is not far different from the national scenario. For instance, majority of the population still reside in the rural areas and they are depended on agriculture for their livelihood sustenance. The poor land tenure system lead to fragmented and marginal farm holdings while those residing along the water bodies engaged in highly contracted artisanal fishing. However for majority of rural dwellers, income earned from these occupations do not meet the needs of the household, hence households are often faced with the option of occupation diversification.

Literature has shown that majority of rural farmers in Nigeria are poor, implying that they have poor asset base that cannot adequately sustained them (Akpan et al., 2016). Hence given a strong correlation between poverty and assets owned, hence there is an overwhelming need to assess the asset profile of these rural farmers. Household livelihood options are influenced by the access to bundle of assets owned by it. According to Chambers and Conway (1992), these enable the household to respond to shocks such as poverty, climate change, changes in price, flood and drought among others. Some households do not live sustainably as a result of change in climate, price change/risk, poverty, inflation etc. However, Haddad and Hoddinott (1997), found out that a household can only survive changes based on the assets owned by them and how they can possibly utilized these assets to cope with and enable them have a sustainable living. A household with higher level of education has a 
higher potential to adopt sustainable livelihood strategies associated with better food security (Savath, Diana, Amber \& Florence, 2014).

As noted by Odero, (2006), the five principal assets mentioned previously are important to sustainable livelihood in rural farming households. He presented these assets in form of pentagon and asserted that; their balance changes from household to household and over time. Following this scholarly work, it is observed that, once these assets have been identified and assessed in terms of their contributions to household livelihood sustainability and presented in a pentagonal graph, it is quite easy to analyse the household vulnerability (i.e. shock, trend and stresses) to any category of asset in respect to household sustainable livelihood. In this manner and as one of the ways to ascertain the sustainability of farming household livelihood, it is important to access the availability of these principal assets in a bit to proffer solutions during shocks or stresses. When responding to shocks, as well as during life transformations, households deploy their assets in different combinations to try to meet livelihood goals (Bharwani et al., 2008; Moench, 2005). It implies that, the knowledge of asset profile of a group can help government and donor agents to decide on the magnitude of intervention or help during or after major disaster. Therefore, an accurate and realistic understanding of people's assets is crucial to be able to analyse how they endeavour to convert their assets into positive livelihood outcomes (Bebbington, 1999). Hence, farmers being the most vulnerable group to shock and the persistency of these shocks in the rural areas as well as the need to generate reliable data base for future plans and interventions in times of shocks, the study specifically sought to:

1) analyse the socio economic features of farming household heads in relation to sustainable livelihood asset capacity of households,

2) to identify different types of assets owned by household in the study area, and

3) show the prevailing capacity structure of sustainable livelihood assets among farming households in the study area.

\section{Methodology}

\subsection{Study Area}

The study was carried out in Abak LGA local government area of Akwa Ibom State, Nigeria. Abak lies on the South West of Akwa Ibom State and is bounded in the North by Ikono Local Government Area, North West by Essien Udim Local Government Area, West by Etim Ekpo and Ukanafun Local Government Areas, South by Oruk Anam and in the East by Uyo Local Government Area. Abak has a population of 139,090 people which comprised of 73,578 males and 65,512 females (2006 National census). The inhabitants are generally Annang, and are predominantly farmers, craftsmen and traders.

\subsection{Sampling Procedures and Sampling Size}

The entire farming households in Abak LGA constituted the sampling frame. However, the representative samples were selected using multi - stage random sampling technique. In the first stage, three clans were randomly selected from the five clans in the study area. These were; Abak urban, Otoro and Midim. In the second stage, 20\% of villages in each of the three clans were randomly chosen. This was to achieve proportional sampling across the three clans selected for the study. A total of 11 villages were randomly individuated from the 3 clans picked. In the third stage; total of (10) farming households were randomly selected from each village, thus making it a total of 110 respondents from all the villages used in the study. Respondents were members of farming households.

\subsection{Instruments and Type of Data Collected}

Cross sectional data were collected from respondents by the use of well-structured questionnaires. In order to authenticate information obtained from the respondents, personal interview and visual observations were used to complement the primary form of data collection.

\subsection{Analytical Technique}

Data generated were subjected to descriptive analysis. Several descriptive tools such as; frequencies, percentages and charts were employed. Households' asset intensity was used to generate asset capacity index for each category of asset.

\section{Results and Discussion}

\subsection{Analysis of the Socioeconomic Characteristic of the Respondents}

The socio economic characteristics of sampled households is summarized and presented in Table 1 and 2 . The result shows that the majority $(51.0 \%)$ of the respondents were within the age range of $50-64$ years, $31.0 \%$ fell in 
the age range of $35-49 ; 13.0 \%$ were in the age range of $20-34$ years while $5.0 \%$ belong to the age range of 65-69. The finding suggests that, majority of respondents were aged and about $44.00 \%$ were still in their active and vibrant age.

This shows that, respondents have potential to accumulate assets. The distributions of respondents according to gender highlight that majority of the respondent $(51.0 \%)$ were male while $49.0 \%$ were female. This finding suggests that, household headship is dominated by the male folks, which is in line with the culture of the study area.

The result further revealed that, $70 \%$ of the respondents were married, while $20.9 \%$ were single and $5.5 \%$ were widowed. Only $3.6 \%$ of the respondents were divorced. These data suggests the high value attached to marital union in the area. The high percentage of married people in the region indicates that most households still maintained the value system for family institution and this will have a strong correlation with asset structure in the area. Also, the structure of formal educational status of respondents revealed that; $20.9 \%$ completed primary education, $53.63 \%$ went through secondary education, while $17.27 \%$ had tertiary education. However $8.2 \%$ of the interviewed had no form of formal education.

Table 1. Socioeconomic characteristics of the respondents

\begin{tabular}{|c|c|c|}
\hline Variable & Frequency & Percentage \\
\hline \multicolumn{3}{|l|}{ Age (Year) } \\
\hline $20-34$ & 7 & 13.00 \\
\hline $35-49$ & 27 & 31.00 \\
\hline $50-64$ & 45 & 51.00 \\
\hline $65-69$ & 31 & 5.00 \\
\hline Total & 110 & 100.00 \\
\hline \multicolumn{3}{|l|}{ Gender (Dummy) } \\
\hline Male & 56 & 51.00 \\
\hline Female & 54 & 49.00 \\
\hline Total & 110 & 100.00 \\
\hline \multicolumn{3}{|c|}{ Marital Status (Dummy) } \\
\hline Single & 23 & 20.90 \\
\hline Married & 77 & 70.00 \\
\hline Divorced/separated & 4 & 3.60 \\
\hline Widowed & 6 & 5.50 \\
\hline Total & 110 & 100.00 \\
\hline \multicolumn{3}{|c|}{ Educational Status (Years) } \\
\hline No formal education & 9 & 8.20 \\
\hline Primary & 23 & 20.90 \\
\hline Secondary & 59 & 53.63 \\
\hline Tertiary & 19 & 17.27 \\
\hline Total & 110 & 100.00 \\
\hline \multicolumn{3}{|l|}{ Income (Naira) } \\
\hline $15,000-34,000$ & 22 & 20.00 \\
\hline $35,000-55,000$ & 35 & 31.82 \\
\hline $55,000-74,000$ & 39 & 35.45 \\
\hline $75,000-95,500$ & 14 & 12.73 \\
\hline Total & 110 & 100.00 \\
\hline
\end{tabular}




\begin{tabular}{lcc}
\hline Household Size (Number) & & \\
$1-3$ & 8 & 7.27 \\
$4-6$ & 31 & 28.18 \\
$7-10$ & 44 & 40.00 \\
$11-15$ & 25 & 22.73 \\
15 and above & 2 & 1.82 \\
Total & $\mathbf{1 1 0}$ & $\mathbf{1 0 0 . 0 0}$ \\
\hline
\end{tabular}

Source: derived from field survey data, 2015.

The years of formal education has great significance on a household's ability to cope with sustainable livelihood capacity.

Given the number of years of acquisition of formal education by respondents, it implies that, the productive capacity of respondents in terms of skills and knowledge is expected to be high and thus their ability to work and earn income. The knowledge acquired is expected to increase the level of their livelihood sustainability through increase in income and asset accumulation. However, this expectation was a mirage given the distribution of monthly income among respondents in the study area.

Table 2. Socioeconomic characteristics of the respondents (continue)

\begin{tabular}{lcc}
\hline Variable & Frequency & Percentage \\
\hline Type of residential house & 5 & 4.55 \\
Mud with thatch roof & 20 & 18.18 \\
Mud with zinc roof & 77 & 70.00 \\
Concrete/bungalow & 8 & 7.27 \\
Storey building & $\mathbf{1 1 0}$ & $\mathbf{1 0 0 . 0 0}$ \\
Total & & \\
Ownership structure of house & 71 & 64.55 \\
Owned & 39 & 35.45 \\
Rented & $\mathbf{1 1 0}$ & $\mathbf{1 0 0 . 0 0}$ \\
Total & & \\
Method of acquisition of house & & 16.36 \\
Outright purchase & 71 & 64.55 \\
Inheritance & 21 & 19.09 \\
Family house & $\mathbf{1 1 0}$ & $\mathbf{1 0 0 . 0 0}$ \\
Total & & \\
Secondary employment status & 43 & 39.09 \\
Self- employed & 8 & 7.27 \\
Unemployed & 59 & 53.64 \\
Employed & $\mathbf{1 1 0}$ & $\mathbf{1 0 0 . 0 0}$ \\
Total & &
\end{tabular}

Source: field survey data, 2015.

The result showed that; the $35.5 \%$ of the respondents earned monthly income ranging from $\$ 55,500$ to $\$ 74,000$; the $31.8 \%$ earned in the range of $\$ 35,000$ to $\$ 55,000$; the $20.0 \%$ earned from $\$ 15000$ to $\$ 34,000$, while the $12.7 \%$ of the respondents realized earned income ranging from $\$ 75,000$ to $\$ 95,500$. Given the current inflation rate and the volatility in household income as reported by many researchers, it could be infer that most 
respondents income in the study area are low and will likely affect the capacity to accumulate asset of any type. The household size of respondents revealed that; the majority (40\%) of farming households have household size ranging from 7-10 persons; while $22.7 \%$ has more than 10 persons in the household. About $28.2 \%$ of the sampled households consisted of 4 - 6 persons; while 7.3\% had 1-3 members. Only small proportion representing about $1.8 \%$ of the respondents' had conspicuously large family size greater than 15 members. Household size has been noted to affect family labour and it is a veritable source of human asset especially in developing economies (Subba-Reddy et al., 2004). Literature has also provided substantial evidence that large sized families have more livelihood diversification tendencies and opportunities resulting in higher livelihood assets status (Stephen and Lenihan, 2010). Increasing diversification could be as the result of increase in household expenditure and migration of older members to economically viable areas in order to generate sufficient income to augment family expenditure. It is also worthy to note; that increase in migration among older members of the family would likely increase the volume of remittances accrual to the benefitting families and this will have a positive impact on household's asset accumulation.

In assessing some of the asset of respondents, the result revealed that, $70 \%$ of the households in the study area live in a concrete house or bungalow; $18.2 \%$ live in a mud with a zinc roof, about $7.3 \%$ live in storey building and the $4.5 \%$ resident in mud house with a thatch roof. From the analysis, it is observed that most farming households in the area have substantial sustainable livelihood capacity in terms of being able to amass physical, financial and human assets. In addition, the data further indicate that; about $64.5 \%$ of respondents live in their own houses while (35.5\%) live in rented shelter. This finding supports the earlier assertion that farming households in the study area have potentials for increase sustainable livelihood capacity. It cab be stated that; the majority of households are aware of the need to accumulate physical asset in order to sustain and improve on their livelihood activities. The proportion of respondents that owned houses is also an indication of the fact that; they are aware of the need for safe guarding human asset like children, education and family's wellbeing etc. It also supports the notion that; farming households is responsive to environmental influences such as; - change in climate, flood and wild wind among others.

In terms of ownership structure of residential building among respondents, it is revealed that, about $64.5 \%$ of respondents inherited their residential houses; while $16.4 \%$ acquired through purchased and only $19.1 \%$ still live in their family owned property. This result indicates that, farming households are aware of the need to accumulate physical properties. Another important feature that has a strong correlation with asset accumulation is the secondary employment status of respondents. Analysis revealed that, $53.6 \%$ of the respondents had secondary occupation while $39.1 \%$ were self-employed, and the $7.3 \%$ were unemployed. This implies that majority of the respondents have alternative means of livelihood survival apart from farming.

\subsection{Respondent Access to Social Services}

The need to access efficiently, the social amenities or services available to rural farmers is crucial for evaluation of asset accumulation as it helped to subsidize the cost of livelihood activities. Table 3 presents the summary of the extent of accessibility of farming households to social services in their domains. Findings have revealed that, all respondents have access to one form of social service or the other; but the extent of accessibility varies across respondents. It is discovered that majority of respondent have access to market; pipe borne water, electricity, mobile phone network, access road and social group.

Table 3. Access to social services by the respondents

\begin{tabular}{lcc}
\hline Social services & Frequency & Percentage \\
\hline Market & 108 & 99 \\
Pipe borne water & 99 & 90.9 \\
Electricity & 93 & 85.4 \\
GSM network & 90 & 81.8 \\
Village town halls & 88 & 80 \\
Motorable roads & 88 & 80 \\
Public medical services & 77 & 70 \\
Library & 54 & 46.4 \\
\hline
\end{tabular}

Source: field study 2015. 
This implies that there is a high rate of social activities which brings farmers together in the study area. Also, there are good levels of social infrastructures that is capable of supporting sustainable livelihood activities among respondents.

\subsection{Analysis of the Asset Profile of Farming Households in the Study Area}

Following thorough reviewed of the literature, several categories of asset were identified. These include: physical, human, social, financial and natural assets. Each of these categories was critically analyse to examine the status of these assets among respondents.

Table 4. Physical assets owned by the farming households

\begin{tabular}{|c|c|c|}
\hline Physical Asset & Percentage/Frequency & Rank \\
\hline Radio & $99.1(109)$ & $1^{\mathrm{st}}$ \\
\hline Fan & 99.1 (109) & $1^{\text {st }}$ \\
\hline Tables & $99.1(109)$ & $1^{\text {st }}$ \\
\hline Kerosene Stove & $99.1(109)$ & $1^{\text {st }}$ \\
\hline Wall clock & $99.1(109)$ & $1^{\text {st }}$ \\
\hline Spade & $99.1(109)$ & $1^{\text {st }}$ \\
\hline Hoe & $99.1(109)$ & $1^{\text {st }}$ \\
\hline Cutlass/matchet & $99.1(109)$ & $1^{\text {st }}$ \\
\hline Television & $99.0(108)$ & $2^{\text {nd }}$ \\
\hline Generator & $93.6(103$ & $3^{\text {rd }}$ \\
\hline GSM handset & $92.7(102)$ & $5^{\text {th }}$ \\
\hline Home theatre/DVD & $89.1(98)$ & $6^{\text {th }}$ \\
\hline Personal/owned land & $83.6(92)$ & $6^{\text {th }}$ \\
\hline Buildings (residential) & $83.6(92)$ & $6^{\text {th }}$ \\
\hline business/shops & $83.6(92)$ & $6^{\text {th }}$ \\
\hline Set of cushion & $79.1(87)$ & $7^{\text {th }}$ \\
\hline Refrigerator & $63.6(70)$ & $8^{\text {th }}$ \\
\hline Motorcycle & $57.3(63)$ & $9^{\text {th }}$ \\
\hline Bicycle & $53.6(59)$ & $10^{\text {th }}$ \\
\hline Water dispenser & $50.9(56)$ & $11^{\text {th }}$ \\
\hline Shovel & $46.4(51)$ & $12^{\mathrm{st}}$ \\
\hline electric cooker & $36.4(40)$ & $13^{\text {th }}$ \\
\hline Well & $26.4(29)$ & $14^{\text {th }}$ \\
\hline Watering can & $22.7(25)$ & $15^{\text {th }}$ \\
\hline Tricycle & $20.9(23)$ & $16^{\text {th }}$ \\
\hline Computer sets & $16.4(18)$ & $17^{\text {th }}$ \\
\hline gas cooker, & $14.5(16)$ & $18^{\text {th }}$ \\
\hline Microwave oven & $14.5(16)$ & $18^{\text {th }}$ \\
\hline $\mathrm{AC}$ & $9.00(10)$ & $19^{\text {th }}$ \\
\hline Car & $6.40(7)$ & $20^{\text {th }}$ \\
\hline
\end{tabular}

Source: field survey, data 2015.

The summary of the physical asset of respondents is presented in Table 4. The findings showed that; the most common physical assets among farming households in this context are; cutlass/matchet, fan, spade, Kerosene 
stove, wall clock, hoe, radio, television and tables. This implies that, almost all the respondents owned these assets that represent the basic necessity of livelihood sustainability. For instance, farming households need matchet, spade and cutlass to help them in farm operations. Another important set of assets available to respondents were: GSM phone, home theatre, generator and buildings. It is observed that accumulation of these assets is in line with the livelihood activities of respondents. The societal needs also prompted the acquisition of these assets. For instance, the epileptic supply of public electricity warrants many people to sort for alternative source of power. In addition, the globalization of economic activities also necessitates the acquisition of mobile phones by respondents.

The result also showed that, the least physical assets owned by respondents were car, air conditioner, gas cooker, micro-wave oven, computer sets and tricycle. However, it is the cost implication and the need for these assets that reduce its accumulation.

\subsection{Social Assets Owned by Respondents}

Table 5 shows the type of social assets owned by farming households sampled in the study area. It resulted that; almost all of the respondents have cousins, aunties and uncle or relatives alive. It is also clear that about $99.1 \%$ and $98.2 \%$ of respondents have access to market and schools respectively. The result further revealed that, access to hospital and non-governmental as well as motorable roads were among the important social assets available for respondents in the experimental region. Farmers' organization or social capital formation also constitutes an important source of social capital among farming households in the region.

However, the study identified less participatory social assets among respondents such as; funeral aid group, members of non-farm cooperative, members of political party and labour exchange group as well as the faith based organization. The finding shows the importance of social asset towards sustainable livelihood activities of farming households. Social assets offer mechanisms for the people to help each other in times of need, solve internal conflicts, and thus reducing powerlessness and mitigate adverse effects of immediate social problems.

Table 5. Types of social assets owned by households

\begin{tabular}{lcc}
\hline Social Assets & Yes & Rank \\
\hline Cousins, Aunties, Uncles(relatives) & $99.1(109)$ & $1^{\text {st }}$ \\
Access to Market & $99.1(109)$ & $1^{\text {st }}$ \\
School & $98.2(108)$ & $2^{\text {nd }}$ \\
Access to hospital & $85.5(94)$ & $3^{\text {rd }}$ \\
Non-governmental organizations & $81.8(90)$ & $4^{\text {th }}$ \\
Access to motorable roads & $76.4(84)$ & $5^{\text {th }}$ \\
Farmers organization & $66.4(73)$ & $6^{\text {th }}$ \\
Faith based organization & $32.7(36)$ & $7^{\text {th }}$ \\
Labour exchange group (efi mbere) & $30.0(33)$ & $8^{\text {th }}$ \\
Member of Political Party & $29.1(32)$ & $9^{\text {th }}$ \\
Members of Non-farm Cooperatives & $19.1(21)$ & $10^{\text {th }}$ \\
Funeral aid group & $14.5(16)$ & $11^{\text {th }}$ \\
\hline
\end{tabular}

Source: Field survey data 2015.

Note, multiple responses were allowed.

\subsection{Profile of Human Assets among Respondents}

Table 6 depicts the type of human assets owned by farming households in the study. The human assets were sub divided into; access to form of formal education, presence of educated or professional skills, presence of vocational skills, and access to health facilities. 
Table 6. Type of human assets owned by the households

\begin{tabular}{lccc}
\hline Education & YES & NO & Rank \\
\hline Science \& technical related & $38.2(42)$ & $61.8(68)$ & $13^{\text {th }}$ \\
Art related & $50.9(56)$ & $49.1(54)$ & $8^{\text {th }}$ \\
Social science related & $57.3(63)$ & $42.7(47)$ & $5^{\text {th }}$ \\
\hline Skills(educated) & & & \\
\hline Medical practitioners & $36.4(40)$ & $63.6(70)$ & $14^{\text {th }}$ \\
Lawyer & $40.9(45)$ & $59.1(65)$ & $12^{\text {th }}$ \\
Engineering & $40(44)$ & $60(66)$ & $11^{\text {th }}$ \\
Farmer & $52.7(58)$ & $47.3(52)$ & $6^{\text {th }}$ \\
Teacher & $51.8(57)$ & $48.2(53)$ & $7^{\text {th }}$ \\
Others(specify) & $33.6(37)$ & $66.4(73)$ & $15^{\text {th }}$ \\
\hline Skills(vocational training) & & & \\
\hline Apprentice & $82.7(91)$ & $17.3(19)$ & $2^{\text {nd }}$ \\
\hline Health & & & $3^{\text {rd }}$ \\
\hline Self- medication & $70(77)$ & $30(33)$ & $16^{\text {th }}$ \\
Family doctor & $17.3(19)$ & $82.7(91)$ & $4^{\text {th }}$ \\
Faith based health services & $67.3(74)$ & $32.7(36)$ & $10^{\text {th }}$ \\
Conventional hospital & $41.8(46)$ & $58.2(64)$ & $1^{\text {st }}$ \\
Traditional medicine & $84.5(93)$ & $15.5(17)$ & $9^{\text {th }}$ \\
Extension services & $44.5(49)$ & $55.5(61)$ & \\
\hline
\end{tabular}

Source: field survey data 2015.

Note: *multiple responses were allowed.

It is evident that; farming households have access to various health facilities; more of educated or professional skills, and educational institutions. In terms of vocational skills they have more of apprentice, for health facility category they have more of traditional medicine, self-medication and faith base medical services. Under form of formal education; art related courses and social sciences were predominant among respondents. Science and technical related courses were less admired by the respondents. Being a farmer, teacher or a lawyer was largely conspicuous among the professional class. However, the least human assets owned by the farming households were medical professionals, lawyers, family doctors and science related education.

\subsection{Types of Financial Assets Owned by the Households}

Table 7 shows that; the major financial assets owned by the households were income obtained from farm $(68.2 \%)$, while the least financial assets were grants $(42.0 \%)$ and transfer payment from relatives $(47.0 \%)$. 
Table 7. Types of financial assets owned by the households

\begin{tabular}{clcc}
\hline & Financial/Economic assets & Yes & Rank \\
\hline 1 & Income from farm & $68.2(75)$ & $1^{\text {st }}$ \\
2 & Cash at hand & $62.7(69)$ & $2^{\text {nd }}$ \\
3 & Income from other jobs & $60.9(67)$ & $3^{\text {rd }}$ \\
4 & Remittances & $60.0(66)$ & $4^{\text {th }}$ \\
5 & Savings in bank & $59.1(65)$ & $5^{\text {th }}$ \\
6 & Jewellery & $56.4(62)$ & $6^{\text {th }}$ \\
7 & Liquid assets & $46.4(51)$ & $7^{\text {th }}$ \\
8 & Insurance & $46.4(51)$ & $8^{\text {th }}$ \\
9 & Pension & $44.5(49)$ & $9^{\text {th }}$ \\
10 & Transfer payment from relatives & $42.7(47)$ & $10^{\text {th }}$ \\
11 & Grants & $38.2(42)$ & $11^{\text {th }}$ \\
\hline
\end{tabular}

Source: Field survey data 2015.

Note:*multiple responses are allowed

Cash at hand and income derivable from other jobs as well as remittances also form prominent parts of financial asset of respondents. Furthermore, savings in banks, liquid assets and worth of jewelleries constituted another important set of financial asset available to farming households in the study area. However, insurance and pension were not prominent in the financial profile of respondents. The finding shows that financial asset facilitates the ownership of physical asset.

\subsection{Natural Assets Owned by the Households}

The result $\mathrm{n}$ Table 8 shows that majority of the natural assets accessed by households includes firewood $(68.20 \%)$, economic tree $(60.9 \%)$, family land $(59.10 \%)$ and water bodies $(57.3 \%)$. However, the least natural assets accessed by the respondents were: wild life, waste disposal outfit and non-timber products. The findings implies that most of the respondents are rural dwellers and have access to land and other natural assets which can be used for productive purposes to support their livelihood activities (DFID, 2000; Nicol, 2000)

Table 8. Type of natural assets owned by the households

\begin{tabular}{clcc}
\hline $\mathrm{s} / \mathrm{n}$ & NATURAL ASSETS & Yes & Rank \\
\hline 1 & Gathering of firewood & $68.2(75)$ & $1^{\text {st }}$ \\
2 & Economic Trees & $60.9(67)$ & $2^{\text {nd }}$ \\
3 & Family land & $59.1(65)$ & $3^{\text {rd }}$ \\
4 & Water bodies & $57.3(63)$ & $4^{\text {th }}$ \\
5 & Community land & $52.7(58)$ & $5^{\text {th }}$ \\
6 & Waste assimilation/ disposal & $45.5(50)$ & $6^{\text {th }}$ \\
7 & Hunting of wildlife & $44.5(49)$ & $7^{\text {th }}$ \\
8 & Gathering of non-timber product & $43.6(48)$ & $8^{\text {th }}$ \\
\hline
\end{tabular}

Source: field survey data 2015.

Note: *multiple responses are allowed

\subsection{The Capacity Structure of Assets of the Respondents}

The capacity structure of asset represents the intensity of each category of asset among respondents. Table 9 contains the estimated capacity index of respondents for each of the category of asset studied. The capacity index was greater for the physical asset compared to the rest of the categories. This index for the natural, financial and 
human assets as well as the social asset revealed the order of importance of these categories of household assts.

Table 9. The asset capacity structure of households

\begin{tabular}{llc}
\hline $\mathbf{s} / \mathbf{n}$ & Asset & Capacity index \\
\hline 1 & Physical asset & 3.099845 \\
2 & Natural asset & 3.004167 \\
3 & Social asset & 2.904545 \\
4 & Financial asset & 2.870179 \\
5 & Human asset & 2.814773 \\
\hline
\end{tabular}

Source: estimated by authors.

\subsection{Capacity Structure of Households in the Study Area}

Figure 1 is a pentagon showing the capacity structure of farming households in the study area. From the diagram, it can be observed that this capacity is skewed and does not form a perfect pentagon. The asset with the highest capacity is the physical asset (3.099845), followed by natural asset (3.00419), social asset (2.904545), financial asset (2.870179) and human asset (2.814773). The human asset has the least capacity index compared to others. This implies that households have more of physical assets, natural assets and social assets while they have less of financial asset and least of human assets. This structure is not sustainable because it is not represented by a perfect pentagon which should best describes a sustainable livelihood status. As the livelihoods approach is concerned first and foremost with people, it seeks to gain an accurate and realistic understanding of people's strengths (here called "assets" or "capitals"). The pentagon gives information about people's assets presented visually, thereby bringing to life important inter-relationships among various assets. The high capacity of physical asset implies that it can generate multiple benefits to households. Households with access to land (natural capital) are also well-endowed with financial capital, as they are able to use the land not only for direct productive activities but also as collateral for loans. Similarly, livestock may generate social capital (prestige and connectedness to the community) for owners while at the same time being used as productive physical capital.

\subsection{Implication of Estimated Capital Indices}

Natural assets (3.00419): the magnitude of the index implies that, natural capital is readily available and accessible to farming households in the study area. This suggests that households would survive with the help of key environmental resources and services as well as food produced from the natural capital. This also implies that household's secured access to land is high and so they are also likely to be well endowed with financial assets, as they can use the land for productive purposes and to secure loans (Chambers, 1987; DFID, 2000; Nicol, 2000). Households having big size of land holdings will have good economic condition (Nagesha et al., 2006), and more scope for sustainable livelihoods by encompassing appropriate combinations of farm enterprises. 


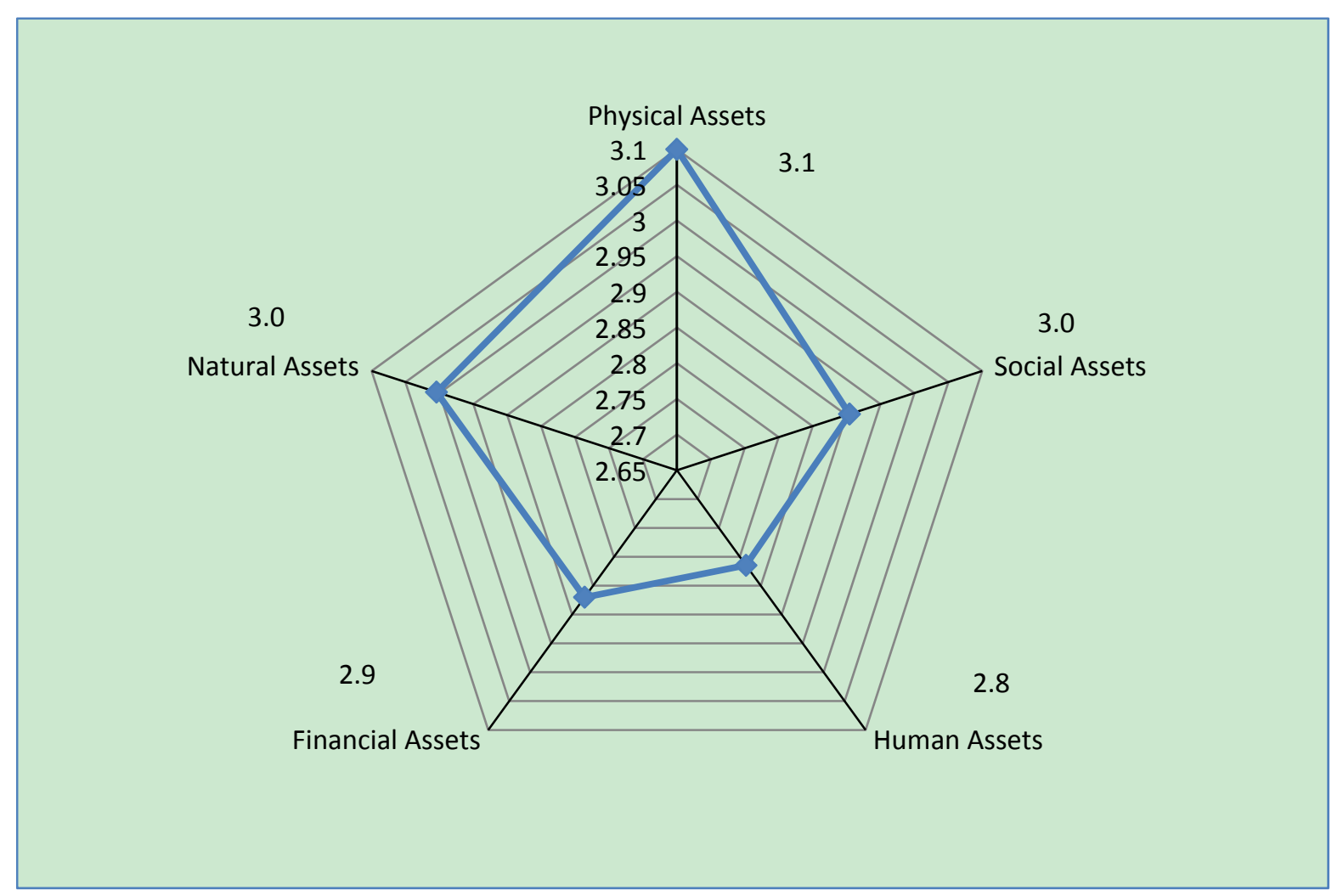

Figure 1. Asset Capacity Structure of Households in Abak Local Government Area, Akwa Ibom State, Nigeria

Social assets (2.904545): The estimated index for social capital reflected modesty in social interaction among farming households. This category of asset has a direct impact upon other types of household capital by improving the efficiency of economic relations, people's incomes and rates of saving (financial capital). Isolated studies have shown that communities with 'higher levels' of social capital are wealthier and more exposed to modern technology. From the asset pentagon it implies that households can be effective in improving the management of common resources (natural capital) and paves way for sharing their views and experiences with other members of the organization. Also, a high social asset capacity implies that Social networks will facilitate innovation, the development of knowledge and sharing of that knowledge, this therefore brings a close relationship between social and human capital. Social capital, like other types of capital, makes a particularly important contribution to people's sense of well-being (through identity, honour and belonging).

Financial assets (2.870179): the magnitude of the index implies that farming households have low economic production potentials and ownership or control of physical capital. The financial asset is needed to acquire physical assets and it is basically the facilitator of production. Financial asset also define the status of social asset among farming households. Innovations are bought or possess with the help of family's financial asset.

Human assets (2.814773): the human capacity index is the least among all categories of asset studied. This suggests that, human capacity (knowledge and labour or the ability to command labour) required to make use of other forms of assets is not sufficient among farming households in the region. Given the current index of human asset, there is an overwhelming need to boost this resource based among respondents. It is therefore not sufficient, for the achievement of the positive and sustainable livelihood outcomes.

\section{Conclusion and Recommendations}

Sustainable livelihood especially among rural dwellers is one of the prerequisites for the envisaged agricultural development and much talk about revenue diversification in the country. Sustainable livelihood among farming households will help to reduce poverty, crimes; militancy, terrorism and reduce over dependency on government among others. But, sustainable livelihood itself is conditioned by the quality, quantity, accessibility and sometimes affordability of the identified five principal assets including; physical, natural, human, social and financial assets. Hence, sustainability in livelihood of farmers is hinged on the balance in these assets, and it 
degree of resilience to shock or stress. Therefore, this study attempted to reveal the composition of these assets among farming households in Abak local government area, Akwa Ibom State. One of the derivatives of the study has revealed imbalance in the five principal assets for farming households in the State. It is shown that human capital is the least acquired asset among farming households in the region. Also, financial capital is a serious constraint among respondents.

Based on the findings from the study, the following recommendations have been made.

1) households should increase their human assets by educating the younger members of the households, this will enable their knowledge and skills to be improved and thus have the capability to work and produce financial asset and other assets that will enhance a sustainable livelihood outcomes.

2) households should improve their participation in social activities such as religious groups, farmer's organizations, cooperatives etc., this builds membership and trust and also enables people to help others solve their problems and as well share knowledge skills and ideas.

\section{References}

Akpan, S. B., Edet J. U., \& Inimfon V. P. (2016). Sustaining Small Scale Farming: Evidence of Poverty and income Disparity among Rural Farming Households in South- South Region of Nigeria. Path of Science: International Electronic Scientific Journal.

Ashley, C. (2000). Applying livelihood approaches to natural resource management initiatives: Experiences in Namibia and Kenya, ODI Working Paper 134, London: ODI.

Baumann, P. (2000). Sustainable livelihoods and political capital: Arguments and evidence from decentralization and natural resource management in India, Working Paper 136, Overseas Development Institute, London.

Bebbington, A. (1999). Capitals and Capabilities: A Framework for Analyzing Peasant Viability, Rural Livelihoods and Poverty. World Development, 27(12), 2021-2044. https://doi.org/10.1016/S0305-750X(99)00104-7

Bharwani, S. et al. (2008). Dynamic Vulnerability: Learning from NeWater Case Studies (NeWater Deliverable No. D 2.1.2). Oxford: Stockholm Environment Institute.

Chambers, R. (1987). Sustainable livelihoods, environment and development: putting poor rural people first. IDS Discussion Paper 240, Brighton: IDS.

Chambers, R., \& Conway, G. R. (1992). Sustainable rural livelihoods: Practical concepts for the 21st century. IDS Discussion Paper No. 296. IDS, Brighton. Conroy, C and Litvinoff, M (Eds.) (1988) The Greening of Aid: Sustainable Livelihoods in Practice. Earthscan Publications Ltd. London. 65.

Department for International Development (DFID) (2000b). Sustainable Livelihoods-current thinking and practice. Department for International Development, London.

Department for international Development (DFID). (2000a). Sustainable Livelihoods Guidance Sheets. Retrieved February 23, 2017, from http://www.livelihoods.org/info/info_guidancesheets.html

FAO. (2017). FAOSTAT Website, Food and Agriculture Organization of the United Nations. Statistics Division.

Haddad, L., John H., \& Alderman, H. (1997). Intra - household Resource Allocation in Developing Countries: Models, Methods, and Policy. Baltimore: The Johns Hopkins University Press.

Kollmair. M., \& Gamper, J. (2002). The Sustainable Livelihood Approach. Input Paper for the Integrated Training Course of NCCR North-South. Development Study Group. University of Zurich.

Krantz, L. (2001). The Sustainable Livelihood Approach to Poverty Reduction, An Introduction to SIDA, 1-27.

Moench, M. (2005). Water, Climatic Variability and Livelihood Resilience: Concepts, Field Insights and Policy Implications (The Resilience and Freshwater Initiative Policy Paper No. II). Stockholm: Swedish Water House.

Morse, S., McNamara, N., \& Acholo, M. (2009). Sustainable Livelihood Approach: A Critical Analysis of Theory and Practice. Geographical Paper 189, University of Reading, November.

Nagesha, G., \& Gangadharappa, N. B. (2006). Adoption of agroforestry systems in north eastern districts of Karna-taka. My Forest, 42(4), 337-347.

Ngbea, G. T., \& Achunike, H. C. (2014). Poverty in Northern Nigeria. Asian Journal of Humanities and Social 
Studies, 2(2), 266-272.

Nicol, A. (2000). Adapting a sustainable livelihoods approach to water projects: Implications for policy and practice (No. 133): Overseas Development Institute (ODI).

Nicol, A. (2000). Adopting a sustainable livelihoods approach to water projects: Implications for policy and practice, Working Paper No.133, Overseas Development Institute.

Nwagwu, E. J. (2014). Unemployment and Poverty in Nigeria: a link to National Insecurity. Global Journal of Politics and Law Research, 2(1), 19-35.

Odero, K. K. (2006). Information Capital. $6^{\text {th }}$ Assets of Sustainable Livelihood Framework. Discovery and Innovation, 18(2) 83-91. https://doi.org/10.4314/dai.v18i2.15709

Savath, V., Fletschner, D., Peterman, A., \& Santos, F. (2014). Land, assets, and livelihoods: Gender analysis of evidence from Odisha State in India. Paper prepared for presentation at the 2014 World Bank conference on Land and Poverty, Washington DC, Washington, DC: World Bank. https://doi.org/10.2139/ssrn.2405717

Scoones, I. (1998). Sustainable rural livelihoods: A framework for analysis. IDS Working Paper No. 72. Inst. Dev. Studies, Sussex, UK.

Stephen Morse, Nora Mc Namara Moses Acholo. (2009). Sustainable Livelihood Approach. Critical analysis of theory and practice. Geographical Paper No. 189, University of Readings.

Stephen, O., \& Lenihan, E. (2010) Rural Livelihood Insecurity in Etsako East of Edo State, Nigeria. Journal of Sustainable Development, 5(1/2).1-11.

Subba Reddy, S., Raghu Ram, P., Neelakanta Sastry, T. V., \& Bhavani Devi, I. (2004). Agricultural Economics. Published by Vijay Primlani for Oxford \& IBH Publishing Co. Pvt. Ltd., S-155, Panchsheel Park, New Delhi 110017.

Turton, C. (2000). Bangladesh: Livelihood monitoring system: Follow up visit. Somerset, UK: DFID.

\section{Copyrights}

Copyright for this article is retained by the author(s), with first publication rights granted to the journal.

This is an open-access article distributed under the terms and conditions of the Creative Commons Attribution license (http://creativecommons.org/licenses/by/4.0/). 